amount of titanium, has been developed where low thermal expansion, as, for example, in a tuning fork, is required. The magnetic properties of iron-silicon alloys used in transformers, etc., have been shown to be effected by the crystalline orientation of the grains. Better magnetic properties are found in a direction parallel to the edges of the cube than in any other, and a technique has been worked out to ensure that this orientation is, at any rate, largely obtained.

Another example of the development in magnetically soft material are the dust-cores' used in transformers and inductances for telecommunication work. Here, a constant permeability is desired. A reduction in the size of the particles greatly reduces the effective permeability, but stabilizes its value for different magnetic fields as well as reducing the loss due to eddy currents. A carbonyl iron in the form of spherical particles a few thousandths of a millimetre in diameter has been produced in Great Britain for the purpose.

Passing on to the magnetically hard materials, the enormous advances which have been made in this field were outlined; the value with some alloys of applying during the cooling a magnetic field which produces a large increase in the remanence in the direction of the applied field was pointed out. Here, as in the case of the anisotropic silicon-iron, it is important that the design should be such that the material is used in the favourable direction only.

In conclusion, what may be an extremely important development in cast iron was mentioned. This, in brief, is the treatment of the iron in such a way that the graphite formed is of the nodular type characteristic of black-heart malleable iron, which hitherto has only been possible after lengthy heattreatment.

F. C. T.

\section{THE ZOOLOGICAL RECORD}

THE appearance of volume 81 of the Zoological Record, dealing mainly with the literature of 1944 , is worthy of special notice, for this comprehensive bibliography of zoological literature has been pubfished regularly since its foundation in 1864. The Record is still mainly dependent on donations for its production, and until the Zoological Society of London assumed responsibility for its publication it underwent many changes in its direction which might have had a disastrous effect on a less hardy annual.

The object of the Record is to give a reference to every article or book of zoological importance throughout the world that has appeared in the previous year. During the War it was impossible to bring out the volumes to time, and at the moment there is a delay of nearly two years; but as soon as printing conditions are easier it is hoped to get back to the normal practice of completing the Record in the year following the literature to which it refers. The cost of producing such a work is, of course, far beyond the price at which it is sold, and it could scarcely hope to be self-supporting; but a further measure of support might be expected from professional zoologists, some of whom seem to be unaware of its existence. The complete volume, published at $£ 4$ (subscription rate $£ 35 \mathrm{~s}$.), is more suitable for libraries, university departments, etc.; but the sections are issued separately as soon as they are ready, and since their cost ranges from only $2 s$., in the case of the smaller groups, to 6s. for Aves, and a maximum of $15 s$. for Insecta, it should be possible for any zoologist to provide himself with the literature of the group in which he is specially concerned.

There is a mistaken impression that the Zoological Record is only of interest to the systematist, but it is also invaluable to the comparative anatomist, the embryologist and the field naturalist; and publications concerned in a general way with genetics, ecology, and other branches of zoology are also included.

Each reference is allotted to one of the twenty odd sections into which the Record is divided, and then dealt with under three hearlings : (1) Titles, containing complete references to all articles arranged in alphabetical order of the authors' names ; (2) Subject Index, giving a detailed analysis of the subjects dealt with in each article; and (3) Systematic Index, comprising a list of all the animals referred to in the section concerned, including those described as new forms, arranged in systematic order. This arrangement enables the reader to find the information regarding the current zoological literature of any group under the authors' names, under specific subjects, or under the scientific names of animals.

The nature of the service provided by the Zoological Record is illustrated in the following excerpt :

\section{TITLES.}

68.-ChRISTENSEN, J. F. The oocysts of coccidia from domestic cattle in Alabama (U.S.A.), with descriptions of two new species. J. Parasit. Urbana, 27, 1941, pp. 203-220. 2 pls. 1 text fig.

II. SUBJECT INDEX.

STRUCTURE.

SPOROZOA.

Eimeria spp. (including new) from American cattle, CHRISTENSEN, 66.

ECOLOGY.

PARASITISM: Hosts-

MAMMALIA : Bos taurus, intestine (U.S.A.): Eimerio alabamensis spp.n., E. subspherica spp.n. (Sporoz. Coccid.). CHRrsTens

ECONOMICS.

COCOIDIOSIS: Coccidiosis in U.S.A. cattle. CHRISTENSEN, 66. III. SYSTEMATIC INDEX.
4. SPOROZOA. (b) COCCIDIIDA.
Eimeria alabamensis, E. subspherica spp.n. (with key to other spp.) from cattle, U.S.A. CHRISTENSEN, $\mathbf{6 6}$.

It should be emphasized that donations to the Zoological Record are still quite inadequate, and further support is urgently required from institutions and individuals.

Edward Hindle

\section{FORTHCOMING EVENTS}

Tuesday, September 2-Tuesday, September 9 WORLD POWER CONFERENOE (at The Hague, Holland).-Conference on "Fuel Economy".

Friday, September 5

INSTITUTE of ECONOMIC ENGINEERING (at Cowdray H Hll, Henrietta Place, London, W.1), at 7 p.m.-Colonel Bernard Ungerson: "Personnel Selection: Army Experience in its relation to the Problems of sonnel Selection
Industry".

\section{APPOINTMENTS VACANT}

APpuICations are invited for the following appointments on or before the dates mentioned :

IeOTURER-IN-Charge, Chemistri Dhpartment, in the Technical Education Branch of the Department of Public Instruction, SydneyThe Official Secretary, New South Wales Government Offices, 56-57 Strand, London, W.C.2 (September 5).

LEOTCRER IN PHYsIos-The Secretary, University Offices, 38 North Bailey, Durham (September 6).

Assistant Leoturer in Physioal Geography, and an Assistant LECTURER IN CHEMISTRY - The Registrar, University College of Wales, Aberystwyth (September 6 )

LEOTORER IN CHEMISTRY, and a LEGTURER IN PHYSIOLOGY-The Principal, Central 'Technical College, Suffolk Street, Birmingham (September 6). 